Article

\title{
Evaluation of Biogas Production from the Co-Digestion of Municipal Food Waste and Wastewater Sludge at Refugee Camps Using an Automated Methane Potential Test System
}

\author{
Mohammad Al-Addous ${ }^{1, *}{ }^{\mathbb{D}}$, Motasem N. Saidan ${ }^{2, *} \mathbb{D}$, Mathhar Bdour ${ }^{1}$ and \\ Mohammad Alnaief ${ }^{3}$ \\ 1 School of Natural Resources Engineering and Management, Energy Engineering Department, German \\ Jordanian University, P.O.Box 35247, Amman 11180, Jordan; madher.bdour@gju.edu.jo \\ 2 Chemical Engineering Department, School of Engineering, The University of Jordan, Amman 11942, Jordan; \\ 3 School of Applied Medical Sciences, Pharmaceutical and Chemical Engineering Department, German \\ Jordanian University, P.O.Box 35247, Amman 11180, Jordan; mohammad.alnaief@gju.edu.jo \\ * Correspondence: mohammad.addous@gju.edu.jo (M.A.-A.); m.saidan@gmail.com (M.N.S.); \\ Tel.: +962-777-680086 (M.N.S.)
}

Received: 13 November 2018; Accepted: 21 December 2018; Published: 22 December 2018

check for updates

\begin{abstract}
The potential benefits of the application of a circular economy-converting biomass at Za'atari Syrian refugee camps into energy-was investigated in this study. Representative organic waste and sludge samples were collected from the camp, mixed in different ratios, and analyzed in triplicate for potential biogas yield. Numerous calorific tests were also carried out. The tangential benefit of the co-digestion that was noticed was that it lowered the value of the total solid content in the mixture to the recommended values for wet digestion without the need for freshwater. To test the potential methane production, the automated methane potential test system (AMPTS) and the graduated tubes in the temperature-controlled climate room GB21 were utilized. Also, calorific values were determined for the organic waste and sludge on both a dry and a wet basis. The maximum biogas production from $100 \%$ organic waste and $100 \%$ sludge using AMPTS was $153 \mathrm{~m}^{3}$ ton $^{-1}$ and $5.6 \mathrm{~m}^{3}$ ton $^{-1}$, respectively. Methane yield reached its maximum at a Vs sub/Vs inoculum range of 0.25-0.3. In contrast, the methane yield decreased when the Vs sub/Vs inoculum exceeded 0.46. The optimum ratio of mixing of municipal food waste to sludge must be carefully selected to satisfy the demands of an energy production pilot plant and avoid the environmental issues associated with the sludge amount at wastewater treatment plants (WWTPs). A possible ratio to start with is $60-80 \%$ organic waste, which can produce $21-65 \mathrm{~m}^{3}$. biogas ton ${ }^{-1}$ fresh matter (FM). The co-digestion of organic waste and sludge can generate $38 \mathrm{Nm}^{3}$ / day of methane, which, in theory, can generate about $4 \mathrm{MW}$ in remote refugee camps.
\end{abstract}

Keywords: organic waste; MSW (Municipal Solid Waste); sludge; anaerobic digestion; methane; circular economy; Jordan

\section{Introduction}

Jordan is a semi-arid country with scarce fresh water resources and relatively limited agricultural activities [1,2]. Currently, Jordan is ranked second in the world in water scarcity [3-5]. Therefore, the biomass availability in arid and semi-arid regions can be considered to be relatively low compared with non-arid regions [6]. Biomass residues available in Jordan may be derived from localized agriculture-related activities, the organic fraction of municipal solid waste (OFMSW), animal manure, 
and organic industrial wastes [7]. However, the utilization of biomass energy is still limited to the direct combustion process for space heating, and currently has no real industrial utilization.

Jordan is a non-oil producing country, which imports $96 \%$ of its energy supplies [8]. Moreover, Jordan is an upper-middle-income country with a population of 9.53 million inhabitants. Thirty percent of the population are non-Jordanians, and 30\% are registered as refugees. Approximately $80 \%$ of Syrian refugees in Jordan live in urban areas in the north of Jordan; the remaining $20 \%$ live in the Za'atari, Marjeeb al-Fahood, Cyber City, and Al-Azraq camps [9-11]. The influx of refugees into Jordan has significantly increased the demand for energy and water resources, and caused an adverse economic burden in Jordan $[12,13]$.

Due to the Syria crisis, Jordan has issued a response plan for 2016-2018. It is stated in the plan that there will be a gap between the landfill capacity and the total volume of waste produced on a daily basis, which was determined to be 1698 tons per day (indicating that $19 \%$ of organic waste will not be landfilled due to lack of landfill capacity) [14]. Also, the high generation rates of waste (i.e., 55\% organic waste) and its disposal to non-sanitary landfills pose environmental, economic, and social problems $[15,16]$, which is the case at the refugee camps. Consequently, this indicates the necessity of reassessing the way Jordan deals with its municipal solid waste (MSW); i.e., to treat it as a resource and not as a burden. Saidan et al. in 2017 analyzed the waste composition generated at the refugee camps and showed that the OFMSW represents the main waste category, with $53 \%$ of the total MSW [10]. However, Saidan et al. focused only on potential recyclable materials, such as plastics, paper, and cardboard, without investigating the potential of converting organic waste into energy opportunities [10].

Anaerobic digestion (AD) is a viable and cost-effective technology for waste management $[17,18]$. However, the co-digestion of OFMSW and sewage sludge has been proposed to overcome the operational obstacles of having high organics and volatile fatty acid accumulation in the sole digestion of sewage sludge [18-23], with relatively less environmental impact compared with other waste management systems reported in some case studies [24].

The circular economy has been defined in the literature as an alternative to a traditional linear economy (make, use, dispose), where the resources are used for as long as possible, the maximum value is extracted from them whilst in use, and then the products and materials are recovered and reused $[25,26]$. In this context, biogas is a renewable energy that is worth promoting based on the circular economic model [27-29]. Moreover, the waste-to-biogas supply chain ensures that environmental impacts are reduced to a minimum and natural resources are used more efficiently [30,31].

The main objective of the present paper is to study the potential benefits of the application of a circular economy in terms of biomass at refugee camps. To do so, samples of OFMSW and sludge were taken from a camp, mixed in different ratios, and analyzed for their potential biogas yield using an automated methane potential test system.

\section{Materials and Methods}

\subsection{Study Area}

For the purpose of this research, the Za'atari Syrian Refugee Camp (ZSRC) was selected as the study area, which is located approximately 8 miles from the Syrian border $\left(32^{\circ} 17^{\prime} 44.4^{\prime \prime} \mathrm{N} 36^{\circ} 19^{\prime} 25.5^{\prime \prime} \mathrm{E}\right)$. ZSRC is the largest refugee camp in the Middle East, and the second-largest refugee camp in the world [32]. The ZSRC has on average 80,000 residents, and regularly generates 28-50 tons of unsegregated municipal waste per day (40 tons/day on average). The ZSRC's waste management is fully described in the work undertaken by Saidan et al in 2017. However, it is now considered to be the fourth-largest city in Jordan and is gradually evolving into a permanent settlement [33]. Running the ZSRC tends to be expensive due to the high costs of waste treatment and energy supply [34]. In this context, the introduction of a biogas production and energy-producing plant would help to minimize 
the cost of running the refugee camp. As a result of that, progress towards sustainability and better living conditions in the camp can be ensured [35].

\subsection{Waste Sampling and Preparation in the ZSRC}

Due to restrictions on, and control of, access to the ZSRC, the ZSRC's managing personnel provided representative MSW samples over a period of one week together with sludge from the Za'atari wastewater treatment plant (WWTP). However, in order to achieve representative samples, guidelines were provided to the ZSRC's technical personnel. The weight of the sample was $15 \mathrm{~kg}$, and it was delivered as a composite sample.

The MSW sample was harvested for its organic fraction, then the organic fraction was milled down to achieve a particle size of less than $10 \mathrm{~mm}$. This size distribution ensures the homogeneity and repeatability of the test.

\subsection{Preliminary Testing of Waste Samples}

All experiments were conducted in the biogas lab located at the German Jordanian University. The room temperature and humidity in the lab were controlled using an air conditioning system with a set value of $24{ }^{\circ} \mathrm{C}$ and $60 \%$ relative humidity. Within the lab, a climate-insulated room is installed where the temperature is kept at $36^{\circ} \mathrm{C}$.

As a preliminary and an important step in setting up the experiment, detailed information on the volatile solids (VS) and the total solids (TS) in all the experimental content was estimated. This importance arises from the impact of the ratio between the VS of the inoculum and the VS of the substrate on the bio-methane production rates. All experiments were carried out at least in triplicate for each tested parameter, and the corresponding statistical variation is shown.

TS and VS were calculated for the OFMSW, the sludge from the Za'atari WWTP, and the inoculum used in the experiment. The inoculum used in the experiment was received from an anaerobic digester located at the Shallalah WWTP; its TS and VS values were $(1.08 \pm 0.02) \%$ and $(72.22 \pm 11.45) \%$, respectively. The measurement of the VS and TS for all constituents in the experiments was carried out in accordance with DIN 38 414-S2 [36]. For the determination of TS, three crucibles were heated at $105{ }^{\circ} \mathrm{C}$ (the tests were done in triplicate) for an hour, then they were cooled down in a desiccator to room temperature. After that, the crucibles were filled with a sample and weighed. Subsequently, it was placed in the oven overnight at $105{ }^{\circ} \mathrm{C}$, then left to cool down to the ambient temperature. Eventually, the sample's corresponding weight was taken, and the TS in the crucible were calculated. Similarly, after that, VS measurement was conducted using the dried sample from the TS measurement. The dried sample was ground to a particle size of less than $0.25 \mathrm{~mm}$ according to DIN 38409 [37]. Then, the sample was weighed and placed in crucibles, and the sample was heated at $200{ }^{\circ} \mathrm{C}, 300{ }^{\circ} \mathrm{C}$, and $500{ }^{\circ} \mathrm{C}$ for $20 \mathrm{~min}, 30 \mathrm{~min}$, and $5 \mathrm{~h}$, respectively.

After acquiring the TS and VS values for all constituents, the ratio of volatile solids in the substrate to the volatile solid in the inoculum was determined. Then, weight calculations for the different percentages of mixing between the OFMSW and the WWTP sludge were performed. Setting up the reactors for both the GB21 experiment and the automated methane potential test system (AMPTS) is performed in a similar manner; however, the tests operate differently. While the AMPTS operates automatically for both mixing and measurements, the climate room GB21 test requires the readings to be taken, and the mixing to be performed, manually. The experiments were conducted in controlled conditions regarding temperature and environment. The AMPTS has a water bath that self-regulates temperature, and each reaction chamber is submerged in the water bath and closed off to the surrounding environment. Moreover, the climate room is tightly sealed with self-regulating heaters.

Based on the VS values, different co-digestion ratios were selected between the OFMSW and the WWTP sludge and tested accordingly. These ratios were then analyzed by GB21 [38] using the standardized graduated glass tubes in the temperature-controlled climate room and in the AMPTS as well. 


\subsection{Experimental Setup for Aerobic Digestion}

AMPTS equipment (Bioprocess Control, Sweden), due to its accuracy and high throughput, was employed for the on-line measurements of biogas and biomethane flows, which were then used in the determination of the biogas potential of various substrates on a laboratory scale [39]. AMPTS consists of three main components: a digester, a carbon dioxide $\left(\mathrm{CO}_{2}\right)$ fixing unit, and a gas enumerator. The digester is a batch system with automated mixing motors, and each digester is connected through plastic lines to the $\mathrm{CO}_{2}$ fixing unit then to the gas flow enumerator $[40,41]$. Each of these batch reactors (digesters) were kept at a constant $37^{\circ} \mathrm{C}$ throughout the experiment's duration. The volume readings are automatically logged, standardized, and tabulated wirelessly by the system. AMPTS is further described in McEniry et al. (2014) [42] and Bioprocess Control Sweden AB (2014) [43].

The GB21 method was implemented in the present study in the climate room using the eudiometer system. The system consists of 500-ml reactors, where each of them is connected to a eudiometer tube and filled with a buffer solution (The buffer solution consisted of $200 \mathrm{~g} \mathrm{NaCl} / \mathrm{L}$ and $5 \mathrm{~g} / \mathrm{L}$ of citric acid), which traps all biogas produced in the reactors. The climate room was kept at a constant temperature of $36^{\circ} \mathrm{C}$, and the pressure measurements were recorded on a reading basis. The total volume of the gas was measured by measuring the displacement of the buffer solution due to the gas production. Then, the total volume reading was standardized based on the climate room's pressure reading and temperature. The generated biogas volume was collected and eventually analyzed for its composition.

\section{Results and Discussion}

\subsection{Waste Analysis and Characterization}

The TS and VS parameters of the OFMSW, the sludge, and the inoculum were characterized, and the results were considered as a preliminary step to both the AMPTS and the climate room GB21 method test. The TS and VS for the OFMSW samples collected from the ZSRC are shown in Table 1. The TS and VS values for the inoculum are $(1.08 \pm 0.02) \%$ and $(72.22 \pm 11.45) \%$, respectively; the TS and VS values for the sludge are $((1.37 \pm 0.31) \%$ and $(72.99 \pm 14.28) \%)$, respectively.

Table 1. The total solid (TS) and volatile solid (VS) content of the organic fraction of municipal solid waste (OFMSW) samples.

\begin{tabular}{ccccc}
\hline Sample & Water Content (\%) & TS (\%) & VS (\% of Dry Matter (DM)) & Ash Content \% \\
\hline 1 & 81.85 & 18.15 & 86.1 & 13.9 \\
\hline 2 & 88.81 & 11.19 & 85.5 & 14.5 \\
\hline 3 & 77.85 & 22.15 & 86.5 & 13.5 \\
\hline 4 & 79.65 & 20.35 & 85.4 & 14.5 \\
\hline 5 & 79.98 & 20.02 & 84.4 & 15.6 \\
\hline mean & $81.63 \pm 4.26$ & $18.37 \pm 4.26$ & $85.6 \pm 0.8$ & $147.8 \pm 11.1$ \\
\hline
\end{tabular}

To investigate biogas generation potential, it is unnecessary to measure the calorific values of an OFMSW and WWTP sludge, since the calorific value should not be equal to the anaerobic fermentation ability. However, this was done in the present work in order to assess different waste-to-energy options, such as incineration and anaerobic co-digestion. The calorific values of both the OFMSW and the WWTP sludge on a dry basis are shown in Table 2. These values were acquired in accordance with DIN 51900 [44]. It is clear that the calorific values of the OFMSW and the WWTP sludge are relatively low even on a dry basis. The situation is worsened due to the fact that both the WWTP sludge and the OFMSW have a high water content; hence, incineration is not a feasible option in comparison with the biogas production option. 
Table 2. The dry-basis calorific values of the OFMSW and the wastewater treatment plant (WWTP) sludge.

\begin{tabular}{ccc}
\hline WWTP Sludge Sample & Weight $(\mathbf{g})$ & Dry Basis Calorific Value (J/g) \\
\hline 1 & 0.6941 & 12,738 \\
\hline 2 & 0.7972 & 12,656 \\
\hline 3 & 0.7707 & 12,591 \\
\hline 4 & 0.6549 & 12,291 \\
\hline 5 & 0.5803 & 12,170 \\
\hline Mean value \pm SD & & $12489 \pm 219$ \\
\hline OFMSW Sample & Weight (g) & Dry Basis Calorific Value $\mathbf{( J / g )}$ \\
\hline 1 & 0.6837 & 19,205 \\
\hline 2 & 0.4762 & 18,853 \\
\hline 3 & 0.5180 & 19,174 \\
\hline 4 & 0.5690 & 18,543 \\
\hline 5 & 0.5176 & 18,578 \\
\hline Mean value \pm SD & & $18,870 \pm 281$ \\
\hline & &
\end{tabular}

\subsection{Evaluation of the Biogas Production and Performance of AMPTS}

Table 3 and Figure 1 show the yields of bio-methane production from the OFMSW mixed with the Za'atari WWTP's sludge at different ratios. The production volumes are presented in Normal milliliter per gram of volatile solids. The production volume showed a strong correlation with the amount of organic fraction: the greater the percent of OFMSW, the greater the bio-methane yield.

Table 3. Bio-methane production at different mixing ratios.

\begin{tabular}{|c|c|c|}
\hline Sample & $\frac{V S_{\text {substrate }}}{V S_{\text {inoculum }}}$ & ${ }^{*}$ Bio-Methane Production $(\mathrm{Nml} / \mathrm{g} \cdot \mathrm{VS})$ \\
\hline Inoculum & - & $5.2 \pm 2.3$ \\
\hline Reference & 0.24 & $314.4 \pm 6.1$ \\
\hline $100 \%$ OFMSW & 0.22 & $383.3 \pm 21.7$ \\
\hline $80 \%$ OFMSW & 0.22 & $344.9 \pm 14.6$ \\
\hline $60 \%$ OFMSW & 0.22 & $337.9 \pm 17.1$ \\
\hline $40 \%$ OFMSW & 0.21 & $357.9 \pm 21.7$ \\
\hline $20 \%$ OFMSW & 0.22 & $316.6 \pm 17.5$ \\
\hline
\end{tabular}

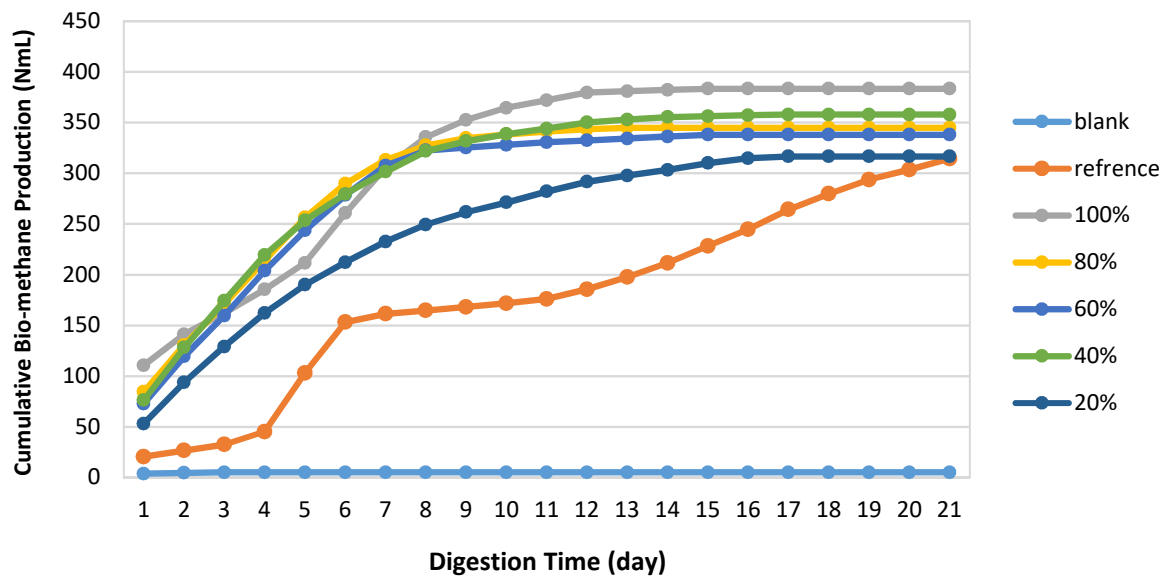

Figure 1. The cumulative bio-methane production volumes per gram of VS (total volumes were recorded by the automated methane potential test system (AMPTS), then divided by the VS values). 
Further, it is clear that most of the biogas production occurred in the first 10 days. Thereafter, a small amount of bio-methane was cumulatively produced (i.e., 4-12\% of the total production).

The AMPTS contains a $\mathrm{CO}_{2}$ fixation unit (where the gas produced in the climate room is trapped in the void between the reactor and the buffer solution). Therefore, it only provides bio-methane production values. Table 4 and Figure 2 show the production volume of biogas. As stated before, the production volume is directly proportional to the amount of OFMSW used.

Table 4. The biogas production at different mixing ratios attained from the climate room system.

\begin{tabular}{|c|c|c|c|c|c|}
\hline & \multirow{2}{*}{$\begin{array}{c}\text { Mixing Ratio } \\
\text { OFMSW-WWTP Sludge }\end{array}$} & \multicolumn{2}{|c|}{ Fresh Matter } & \multirow{2}{*}{$\frac{V S_{\text {substrate }}}{V S_{\text {inoculum }}} *$} & \multirow{2}{*}{$\begin{array}{l}\text { Total Production } \\
\text { (Nml/g VS) }\end{array}$} \\
\hline & & OFMSW (g) & WWTP Sludge (g) & & \\
\hline 1 & $10-90$ & 0.37 & 55 & 0.277 & $261 \pm 43$ \\
\hline 2 & $20-80$ & 1.34 & 80 & 0.457 & $291 \pm 37$ \\
\hline 3 & $30-70$ & 1.2 & 43 & 0.278 & $375 \pm 28$ \\
\hline 4 & $40-60$ & 1.95 & 25 & 0.246 & $520 \pm 22$ \\
\hline 5 & $50-50$ & 1.98 & 31 & 0.275 & $512 \pm 52$ \\
\hline 6 & $60-40$ & 2.37 & 25 & 0.274 & $562 \pm 36$ \\
\hline 7 & $70-30$ & 3.51 & 13 & 0.296 & $605 \pm 25$ \\
\hline 8 & $80-20$ & 5.5 & 20 & 0.462 & $455 \pm 44$ \\
\hline 9 & $90-10$ & 3.56 & 6 & 0.267 & $884 \pm 51$ \\
\hline 10 & $100 \%$ OFMSW & 3.97 & 0 & 0.267 & $824 \pm 34$ \\
\hline 11 & $100 \%$ WWTP sludge & 0 & 62 & 0.284 & $269 \pm 46$ \\
\hline
\end{tabular}

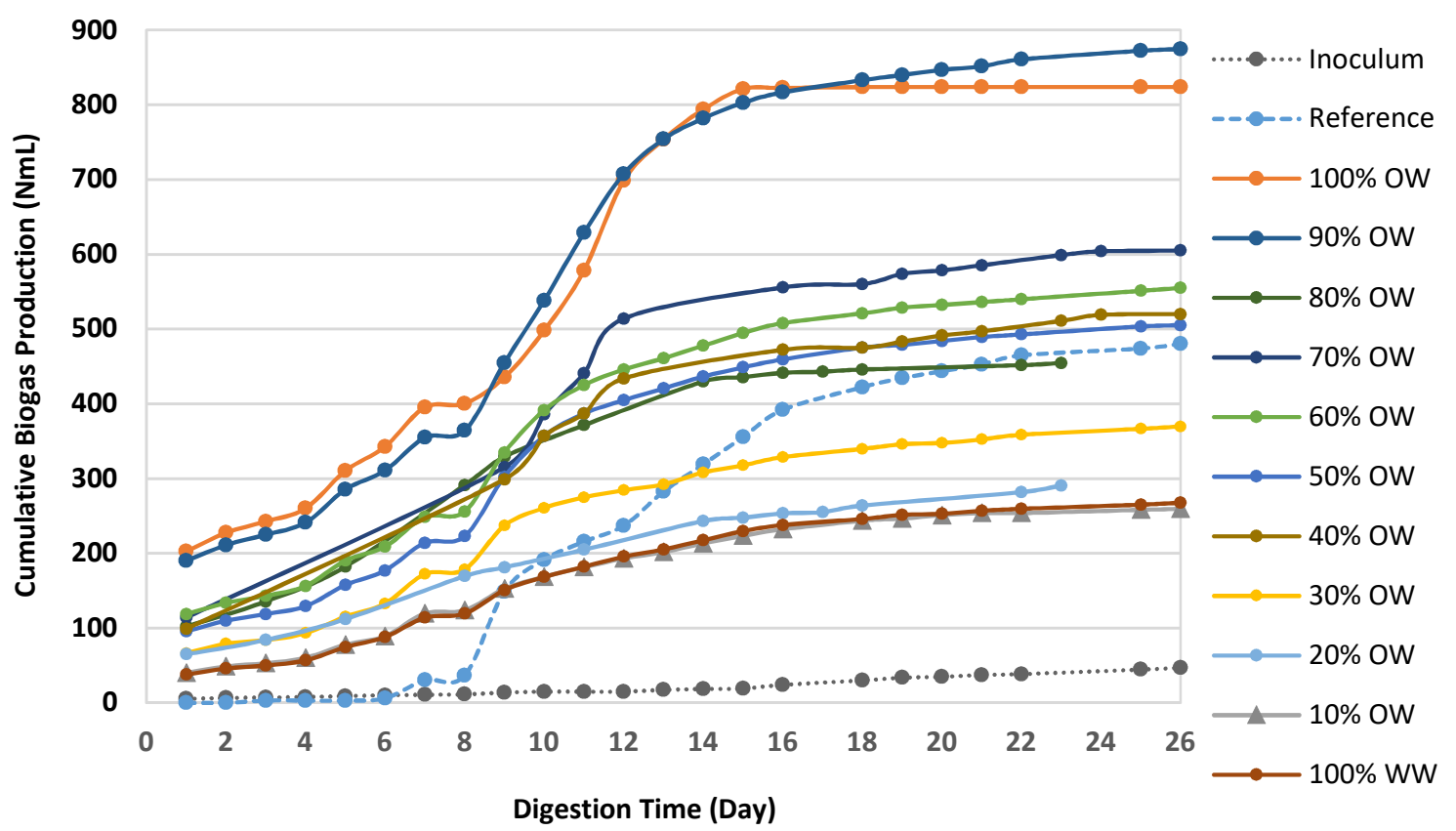

Figure 2. The cumulative biogas production volumes per gram of VS (total volumes were recorded in the climate room system, then divided by the VS values).

Based on the highest methane yield produced as shown in Table 4, it could be considered that a $\mathrm{Vs} \mathrm{sub} / \mathrm{Vs}$ inoculum range of $0.25-0.3$ is the ideal ratio for methane yield. Some offsets can be noticed in Table 4, where two values of Vs sub/Vs inoculum are higher than 0.3: 0.457 at a lower mixing ratio (20-80\%) and 0.462 at a higher mixing ratio (80-20\%). In Figure 2, the cumulative methane trend 
showed no delay (the lag phase) in all experiments. However, for 0.457 at the lower mixing ratio $(20-80 \%)$ and 0.462 at the higher mixing ratio (80-20\%), the biogas ceased after 23 days, while the volume of methane production was slightly lower than that of the $0.25-0.3 \mathrm{Vs}$ sub/Vs inoculum range. This indicates that the amount of micro-organism required for an anaerobic reaction to take place is not enough for the biodegradation process $[45,46]$.

Unlike the AMPTS, the biogas production from the climate room system includes other gases in addition to methane, which is $\mathrm{CO}_{2}$. Therefore, the biogas produced from the climate room system was analyzed for its composition as shown in Table 5, which shows the percentages of $\mathrm{CH}_{4}$ and $\mathrm{CO}_{2}$ in the biogas. Multiplying the percentage of $\mathrm{CH}_{4}$ with the total produced amount of biogas yields $\mathrm{CH}_{4}$ volumes that are relatively close to those found in the AMPTS test, despite the fact that both tests were performed under different (VS substrate/VS inoculum) ratios.

Table 5. The biogas composition at different mixing ratios.

\begin{tabular}{ccc}
\hline Sample & $\mathrm{CH}_{4}(\%)$ & $\mathrm{CO}_{2}(\%)$ \\
\hline Reference & 72 & 28 \\
\hline Inoculum & 59 & 41 \\
\hline $0 \%$ & 66 & 34 \\
\hline $10 \%$ & 61 & 39 \\
\hline $20 \%$ & 67 & 33 \\
\hline $30 \%$ & 66 & 34 \\
\hline $40 \%$ & 67 & 33 \\
\hline $50 \%$ & 67 & 33 \\
\hline $60 \%$ & 65 & 35 \\
\hline $70 \%$ & 66 & 34 \\
\hline $80 \%$ & 62 & 38 \\
\hline $90 \%$ & 67 & 33 \\
\hline $100 \%$ & 65 & 35 \\
\hline
\end{tabular}

The obtained biogas production reported in this work reflects previously reported values for similar substrates. Elbeshbishy et al. investigated in 2012 the bio-methane potential from food wastes and primary sludge, and reported that 400-1400 $\mathrm{L}_{\text {methane }} / \mathrm{kg}$ VS can be produced depending on the used inoculum [47]. Pavi et al. investigated in 2017 the biogas potential of the co-digestion of an OFMSW and fruit and vegetable wastes at different ratios. They found that the best mixing ratio was 1:3 OFMSW to the fruit and vegetables, with an approximate production of $396 \mathrm{Nml} / \mathrm{g}$ VS methane [48]. Fiore et.al studied in 2016 the biogas potential from industrial food-processing waste [49]. In their work, they reviewed several potential types of industrial waste. The results vary from $180 \mathrm{~L}_{\text {methane }} / \mathrm{kg}$ VS for apple pulp to $300 \mathrm{~L}_{\text {methane }} / \mathrm{kg}$ VS for Glycerol $[49,50]$. Moreover, fruit and vegetable waste has been reported to produce $320-630 \mathrm{~L}_{\text {biogas }} / \mathrm{kg}$ VS [51].

\subsection{Biogas Plant Potential and Analysis}

Based on the experimental results, it is recommended to undertake co-digestion of the feed for the pilot biogas plant. The feed should comprise sludge from the ZSRC's WWTP and the organic waste portion of the municipal waste generated at the ZSRC.

For the calculations, and as stated before, the ZSRC has an average population of 80,000, and generates an average of $0.8 \mathrm{~kg} /$ capita per day of daily waste. The MSW composition generated at the ZSRC contains 50\% organic waste. Moreover, the WWTP produces approximately $2000 \mathrm{~m}^{3}$ of sludge on a daily basis. 
In summary, the conducted biogas potential test indicates the following: (1): the organic portion of the municipal waste was about $40-50 \%$, with the TS and VS being $20 \%$ and $15 \%$ of the total amount of solid, respectively; and (2) the total solid in the sludge was about 2-6\% (depending on the sampling location), and the volatile solid was $0.3-3 \%$ of the fresh matter.

The maximum production of biogas from the APMTS system was found for the $100 \%$ organic waste, with an approximate value of $81 \mathrm{~m}^{3}$ of bio-methane per ton of fresh organic waste, while the smallest quantity was for sludge from the WWTP only, with an approximate value of $1.6 \mathrm{~m}^{3}$ of bio-methane per ton of fresh sludge.

One possible scenario to operate a large-scale biogas plant is to use $11 \%$ of the residues as feed to the biogas plant. For that, $500 \mathrm{~kg}$ of the sludge should be mixed with about $280 \mathrm{~kg}$ of organic municipal waste per day. The biogas potential test indicates that about $38 \mathrm{Nm}^{3} /$ day of biogas can be generated. However, the potential percentage of methane that can be generated in the biogas is about $62 \%$. Using a combustion engine to generate heat and electricity with an efficiency of $40 \%$, and taking into consideration the calorific value of methane, $38 \mathrm{Nm}^{3} /$ day can generate about $98,000 \mathrm{kWh} /$ day as electricity, $98,000 \mathrm{kWh} /$ day as thermal energy, or about $4 \mathrm{MW}$ in theory. For that, four digesters are needed, each with a capacity of about $20,000 \mathrm{~m}^{3}$.

\section{Conclusions}

In the present study, it was demonstrated that laboratory-scale testing provides a good basis for the anaerobic co-digestion of the OFMSW and wastewater treatment sludge generated at ZSRC. In addition, the results of AMPTS and climate room testing could be valuable in optimizing critical parameters for the further implementation of anaerobic digestion/co-digestion under continuous operation. Co-digestion of organic waste and sludge increases the dissolved nutrients and water content in the wet fermentation process $(88-95 \%)$. The maximum production of biogas from the APMTS system was from $100 \%$ organic waste, with an approximate value of $81 \mathrm{~m}^{3}$ bio-methane $\cdot$ ton $^{-1}$ fresh organic waste. The smallest quantity was for sludge from the WWTP only, with an approximate value of $1.6 \mathrm{~m}^{3}$ bio-methane ton ${ }^{-1}$ fresh sludge. The results from the climate room system experiments were found to be in good agreement with those of the APMTS system experiments, with slight deviations. The maximum production was found to be from $100 \%$ organic waste, with an approximate production of $153 \mathrm{~m}^{3}$ bio-gas ton ${ }^{-1}$ fresh organic waste and only $5.6 \mathrm{~m}^{3}$ bio-gas ton ${ }^{-1}$ fresh sludge. Optimization of the Vs sub/Vs inoculum ratios plays a vital role in a batch digester's operation. The results indicated that $\mathrm{Vs} \mathrm{sub} / \mathrm{Vs}$ inoculum ratios ranging from 0.25 to 0.3 produce the maximum methane yields. The average composition of the bio-methane in the biogas was $65 \%$, and the remainder was mainly carbon dioxide. The ratio of mixing between the municipal organic waste and the sludge from the WWTP should be chosen carefully to satisfy the demands of an energy production pilot plant and the environmental problems associated with the sludge amount at WWTPs. A possible ratio to start with is $60-80 \%$ organic waste, which can produce $21-65 \mathrm{~m}^{3} \cdot$ ton $^{-1}$ fresh matter (FM). Finally, having a biogas plant at the ZSRC to co-digest organic waste and sludge could generate $38 \mathrm{Nm}^{3}$ /day of methane, which could potentially produce about $4 \mathrm{MW}$ in theory. This represents a potential application of a circular economy at the ZSRC and at other similar camps and small communities.

Author Contributions: Conceptualization, M.A.-A. and M.N.S.; methodology, M.N.S. and M.A.-A.; validation, M.A.-A., M.A., and M.B.; formal analysis, M.A.; investigation, M.B.; resources, M.A.; data curation, M.N.S. and M.A.; writing (original draft preparation), M.A.-A.; writing (review and editing), M.N.S. and M.A.; visualization, M.A.; supervision, M.A.-A.; project administration, M.A.-A. and M.B.; funding acquisition, M.A.-A.

Funding: The authors are thankful for the seed grant fund provided by the deanship of graduate studies and research at the German Jordanian University. The funding for all used equipment was from a project called "Biogas Production in Local Communities in Jordan" that was funded by the European Union.

Conflicts of Interest: The authors declare no conflict of interest. 


\section{Abbreviations}

$\begin{array}{ll}\text { AMPTS } & \text { automated methane potential test system } \\ \text { AD } & \text { Anaerobic digestion } \\ \text { DM } & \text { Dry matter } \\ \text { FM } & \text { Fresh matter } \\ \text { kWh } & \text { Kilo watt hour } \\ \text { MSW } & \text { Municipal solid waste } \\ \text { MW } & \text { Mega watt } \\ \text { OFMSW } & \text { Organic fraction of municipal solid waste } \\ \text { TS } & \text { Total solids } \\ \text { VS } & \text { Volatile solids } \\ \text { WWTP } & \text { wastewater treatment plant } \\ \text { ZSRC } & \text { Za'atari Syrian refugees camp }\end{array}$

\section{References}

1. Saidan, M.N.; Al-Weshah, R.A.; Obada, I. Potential Rainwater Harvesting: Adaptation Measure for Urban Areas in Jordan. Am. Water Works Assoc. 2015, 107, 594-602. [CrossRef]

2. Al-Weshah, R.; Saidan, M.; Al-Omari, A. Environmental ethics as a tool for sustainable water resource management. Am. Water Works Assoc. 2016, 108, 175-181. [CrossRef]

3. Ministry of Water and Irrigation. Jordan's Water Strategy 2016-2025; Ministry of Water and Irrigation: Amman, Jordan, 2016.

4. Aboelnga, H.; Saidan, M.; Al-Weshah, R.; Sturm, M.; Ribbe, L.; Frechen, F.B. Component analysis for optimal leakage management in Madaba, Jordan. J. Water Supply Res. T 2018, 67, 384-396. [CrossRef]

5. Saidan, M.N.; Al-Yazjeen, H.; Abdalla, A.; Khasawneh, H.J.; Al-Naimat, H.; Al Alami, N.; Adawy, M.; Jaber, M.S.; Sowan, N. Assessment of on-site treatment process of institutional building's wastewater. Processes 2018, 6, 26. [CrossRef]

6. Bastidas-Oyanedel, J.R.; Fang, C.; Almardeai, S.; Javid, U.; Yousuf, A.; Schmidt, J.E. Waste biorefinery in arid/semi-arid regions. Bioresour. Technol. 2016, 215, 21-28. [CrossRef] [PubMed]

7. Al-Hamamre, Z.; Saidan, M.; Hararah, M.; Rawajfeh, K.; Alkhasawneh, H.; Al Shannag, M. Wastes and biomass materials as sustainable-renewable energy resources for Jordan. Renew. Sustain. Energy Rev. 2017, 67, 295-314. [CrossRef]

8. Saidan, M. Sustainable Energy Mix and Policy Framework for Jordan; Friedrich Ebert Stiftung: Amman, Jordan, 2012.

9. The UN Refugee Agency. UNHCR-Fact Sheet Zaatari Refugee Camp, The UN Refugee Agency. 2015. Available online: https:/ / data2.unhcr.org/en/situations/syria/location/36 (accessed on 16 July 2018).

10. Saidan, M.N.; Abu Drais, A.; Al-Manaseer, E. Solid waste composition analysis and recycling evaluation: Zaatari Syrian Refugees Camp, Jordan. Waste Manag. 2017, 61, 58-66. [CrossRef]

11. Saidan, M.N.; Abu Drais, A.; Linton, C.; Hamdan, S. Solid waste Characterization and recycling in Syrian refugees hosting communities in Jordan. In Waste Management in MENA Regions, 1st ed.; Negm, A.M., Noama, E., Eds.; Earth and Environmental Sciences Series; Applied Environmental Science and Engineering for a Sustainable Future; Springer International Publishing AG: Basel, Switzerland, 2018; (accepted).

12. Al-Awad, T.K.; Saidan, M.N.; Gareau, B.J. Halon management and ozone-depleting substances control in Jordan. Int. Environ. Agreem. 2018, 18, 391-408. [CrossRef]

13. Alrabie, K.; Saidan, M.N. A preliminary solar-hydrogen system for Jordan: Impacts assessment and scenarios analysis. Int. J. Hydrog. Energy 2018, 43, 9211-9223. [CrossRef]

14. Ministry of Planning and International Cooperation (MoPIC). Jordan Response Plan for the Syria Crisis 2016-2018; Ministry of Planning and International Cooperation: Amman, Jordan, 2016.

15. Saidan, M.N.; Ansour, L.M.; Saidan, H. Management of Plastic BagsWaste: An assessment of scenarios in Jordan. J. Chem. Technol. Metall. 2017, 52, 148-154.

16. Nizami, A.S.; Mohanakrishna, G.; Mishra, U.; Pant, D. Trends and Sustainability Criteria for the Liquid Biofuels. In Biofuels: Production and Future Perspectives; Singh, R.S., Pandey, A., Gnansounou, E., Eds.; CRC Press: Boca Raton, FL, USA, 2016; pp. 59-95. 
17. Pavi, S.; Eduardo Kramer, L.; Paulo Gomes, L.; Alcides Schiavo Miranda, L. Biogas production from co-digestion of organic fraction of municipal solid waste and fruit and vegetable waste. Bioresour. Technol. 2017. [CrossRef]

18. Mehariya, S.; Patel, A.K.; Obulisamy, P.K.; Punniyakotti, E.; Wong, J.W.C. Co-digestion of food waste and sewage sludge for methane production: Current status and perspective. Bioresour. Technol. 2018. [CrossRef] [PubMed]

19. Agyeman, F.O.; Tao, W. Anaerobic co-digestion of food waste and dairy manure: Effects of food waste particle size and organic loading rate. J. Environ. Manage. 2014, 133, 268-274. [CrossRef] [PubMed]

20. Appels, L.; Lauwers, J.; Degrève, J.; Helsen, L.; Lievens, B.; Willems, K.; Van Impe, J.; Dewil, R. Anaerobic digestion in global bio-energy production: Potential and research challenges. Renew. Sustain. Energy Rev. 2011, 15, 4295-4301. [CrossRef]

21. Awasthi, M.K.; Pandey, A.K.; Bundela, P.S.; Wong, J.W.C.; Li, R.; Zhang, Z. Co-composting of gelatin industry sludge combined with organic fraction of municipal solid waste and poultry waste employing zeolite mixed with enriched nitrifying bacterial consortium. Bioresour. Technol. 2016, 213, 181-189. [CrossRef] [PubMed]

22. Chiu, S.L.H.; Lo, I.M.C. Reviewing the anaerobic digestion and co-digestion process of food waste from the perspectives on biogas production performance and environmental impacts. Environ. Sci. Pollut. Res. 2016, 23, 24435-24450. [CrossRef] [PubMed]

23. Al-Addous, M.; Alnaief, M.; Class, C.; Nsair, A.; Kuchta, K.; Alkasrawi, M. Technical Possibilities of Biogas Production from Olive and Date Waste in Jordan. BioResources 2017, 12, 9383-9395.

24. Edwards, J.; Othman, M.; Crossin, E.; Burn, S. Anaerobic co-digestion of municipal food waste and sewage sludge: A comparative life cycle assessment in the context of a waste service provision. Bioresour. Technol. 2017, 223, 237-249. [CrossRef]

25. Morgan, J.; Mitchell., P. Employment and the Circular Economy: Job Creation in a More Resource Efficient Britain; Green Alliance: London, UK, 2015.

26. Andersen, M.S. An introductory note on the environmental economics of the circular economy. Sustain. Sci. 2007, 2, 133-140. [CrossRef]

27. Chen, L.; Cong, R.-G.; Shu, B.; Mi, Z.-F. A sustainable biogas model in china: The case study of beijing deqingyuan biogas project. Renew. Sustain. Energy Rev. 2017, 78, 773-779. [CrossRef]

28. Cong, R.G.; Caro, D.; Thomsen, M. Is it beneficial to use biogas in the Danish transport sector?-An environmental-economic analysis. J. Clean Prod. 2017, 165, 1025-1035. [CrossRef]

29. Xu, F.; Li, Y.; Ge, X.; Yang, L.; Li, Y. Anaerobic digestion of food waste challenges and opportunities. Bioresour. Technol. 2018, 247, 1047-1058. [CrossRef] [PubMed]

30. Ertem, F.C.; Neubauer, P.; Junne, S. Environmental life cycle assessment of biogas production from marine macroalgal feedstock for the substitution of energy crops. J. Clean. Prod. 2017, 140, 977-985. [CrossRef]

31. Volpe, R.; Messineo, A.; Millan, M. Carbon reactivity in biomass thermal breakdown. Fuel 2016, 183, $139-144$. [CrossRef]

32. Ott, S. Syrians at Refugees Camp: We Can't Live Here Forever. Al Jazeera. 24 October 2015. Available online: http:/ / www.aljazeera.com/news/2015/10/syrians-Zaatari-camp-live-151021074641938.html (accessed on 10 July 2018).

33. Sullivan, D.; Tobin, S. Security and resilience among Syrian refugees in Jordan. Middle East Report Online 14 October 2014. Available online: https:/ / merip.org/ (accessed on 1 August 2018).

34. Ledwith, A.; Smith, D. Zaatari: The Instant City Affordable Housing Institute. 2014. Available online: http:/ / sigus.scripts.mit.edu/x/files/Zaatari/AHIPublication.pdf (accessed on 13 August 2018).

35. Ismail, I.M.I.; Nizami, A.S. Waste-based biorefineries in developing countries: An imperative need of time. In Proceedings of the Canadian Society for Civil Engineering: 14th International Environmental Specialty Conference, London, ON, Canada, 1-4 June 2016.

36. German Standard Methods for the Examination of Water, Wastewater and Sludge; Sludge and Sediments (Group S); Determination of Water Content, of Dry Residue and of Solids Content (S 2); DIN 38 414-S2; Beuth Verlag GmbH: Berlin, Germany, 1985.

37. German Standard Methods for the Examination of Water, Wastewater and Sludge; Parameters Characterizing Effects and Substances (Group H); Determination of Total dry Residue, dry Extract and Residue on Ignition (H 1); DIN 38 409; Beuth Verlag GmbH: Berlin, Germany, 1987. 
38. Evaluation of Waste from Mechanical-Biological Treatment_Part 3: Stability Parameters—Gas Generation by Fermentation test (GB21); OENORM S 2027-3; Beuth Verlag: Berlin, Germany, 2012.

39. Badshah, M.; Lam, D.M.; Liu, J.; Mattiasson, B. Use of an Automatic Methane Potential Test System for evaluating the biomethane potential of sugarcane bagasse after different treatments. Bioresour. Technol. 2012, 114, 262-269. [CrossRef] [PubMed]

40. Himanshu, H.; Voelklein, M.A.; Murphy, J.D.; Grant, J.; O'Kiely, P. Factors controlling headspace pressure in a manual manometric BMP method can be used to produce a methane output comparable to AMPTS. Bioresour. Technol. 2017, 238, 633-642. [CrossRef] [PubMed]

41. Kolbl, S.; Paloczi, A.; Panjan, J.; Stres, B. Addressing case specific biogas plant tasks: Industry oriented methane yields derived from 5 L Automatic Methane Potential Test Systems in batch or semi-continuous tests using realistic inocula, substrate particle sizes and organic loading. Bioresour. Technol. 2014, 153, 180-188. [CrossRef]

42. McEniry, J.; Allen, E.; Murphy, J.D.; O'Kiely, P. Grass for biogas production: the impact of silage fermentation characteristics on methane yield in two contrasting biomethane potential test systems. Renew. Energy 2014, 63, 524-530. [CrossRef]

43. Bioprocess Control Sweden AB. AMPTS II (Automatic Methane Potential Test System): Operation and Maintenance Manual; Bioprocess Control: Lund, Sweden, 2014.

44. Testing of Solid and Liquid Fuels-Determination of Gross Calorific Value by the Bomb Calorimeter and Calculation of Net Calorific Value_Part 1: Principles, Apparatus, Methods; DIN 51900-1:2000-04; DIN: Berlin, Germany, 2000.

45. Zhou, Y.; Zhang, Z.; Nakamoto, T.; Li, Y.; Yang, Y.; Utsumi, M.; Sugiura, N. Influence of substrate-to-inoculum ratio on the batch anaerobic digestion of bean curd refuse-okara under mesophilic conditions. Biomass Bioenergy 2011, 35, 3251-3256. [CrossRef]

46. Nazaitulshila, R.; Idris, A.; Harun, R.; Wan Azlina, W.A.K.G. The Influence of Inoculum to Substrate Ratio on the Biochemical Methane Potential of Fat, Oil, and Grease in Batch Anaerobic Assays. Energy Source Part A Recov. Util. Environ. Eff. 2015, 37, 590-597. [CrossRef]

47. Elbeshbishy, E.; Nakhla, G.; Hafez, H. Biochemical methane potential (BMP) of food waste and primary sludge: Influence of inoculum pre-incubation and inoculum source. Bioresour. Technol. 2012, 110, 18-25. [CrossRef] [PubMed]

48. Pavi, S.; Kramer, L.E.; Gomes, L.P.; Miranda, L.A.S. Biogas production from co-digestion of organic fraction of municipal solid waste and fruit and vegetable waste. Bioresour. Technol. 2017, 228, 362-367. [CrossRef] [PubMed]

49. Fiore, S.; Ruffino, B.; Campo, G.; Roati, C.; Zanetti, M.C. Scale-up evaluation of the anaerobic digestion of food-processing industrial wastes. Renew. Energy 2016, 96, 949-959. [CrossRef]

50. Galí, A.; Benabdallah, T.; Astals, S.; Mata-Alvarez, J. Modified version of ADM1 model for agro-waste application. Bioresour. Technol. 2009, 100, 2783-2790. [CrossRef]

51. Gunaseelan, V.N. Predicting ultimate methane yields of Jatropha curcus and Morus indica from their chemical composition. Bioresour. Technol. 2009, 100, 3426-3429. [CrossRef] [PubMed]

(C) 2018 by the authors. Licensee MDPI, Basel, Switzerland. This article is an open access article distributed under the terms and conditions of the Creative Commons Attribution (CC BY) license (http:/ / creativecommons.org/licenses/by/4.0/). 